\title{
Temporal and spatial variation of nitrogen and phosphorus and eutrophication assessment for a typical arid river - Fuyang River in northern China
}

\author{
Wenqiang Zhang ${ }^{1}$, Xin Jin ${ }^{1,2}$, Dong Liu $^{1,3}$, Chao Lang ${ }^{1,3}$, Baoqing Shan ${ }^{1, *}$ \\ 1. State Key Laboratory on Environmental Aquatic Chemistry, Research Center for Eco-Environmental Science, Chinese Academy of Science, \\ Beijing 100085, China. E-mail: wqzhang@rcees.ac.cn \\ 2. University of Chinese Academy of Science, Beijing 100049, China \\ 3. Hebei University of Engineering, Hebei 056038, China
}

\section{A R T I C L E I N F O}

Article history:

Received 2 May 2016

Revised 8 July 2016

Accepted 13 July 2016

Available online 28 July 2016

Keywords:

Arid river

Eutrophication

Nitrogen

Phosphorus

Northern China

\begin{abstract}
A B S T R A C T
Based on water quality surveys over 2 years (July to December, in 2014 and 2015) in a typical arid river in northern China the Xingtai segment of the Fuyang River basin - the variation of nitrogen $(\mathrm{N})$ and phosphorus $(\mathrm{P})$ was analyzed. The extent of water eutrophication of this segment was also assessed using a universal index formula for eutrophic evaluation and a logarithmic power function. The results showed that the average concentration of total $\mathrm{N}$ (TN) was $27.2 \mathrm{mg} / \mathrm{L}\left(\mathrm{NH}_{3}-\mathrm{N}, 63.5 \%\right.$ ), total P (TP) was $2.0 \mathrm{mg} / \mathrm{L}$ (solution reactive phosphorus, $68.8 \%$ ). Temporal and spatial variations of $\mathrm{N}$ and $\mathrm{P}$ in this segment were observed. Concentrations of $\mathrm{N}$ and $\mathrm{P}$ in the arid season were higher than those in the rainy season. Spatially, the $\mathrm{N}$ and $\mathrm{P}$ concentrations followed the same trend; i.e., higher in the city segment than in the suburbs, and decreasing along the river. The water eutrophication in the studied segment reached extremely high levels at all times (eutrophication index $\geq 76.3$ ). Spatially, its trend was clearly linked with $\mathrm{N}$ and P. Water shortage, pollution accumulation and a weak self-purification function are the main reasons for the prominent eutrophication in this segment.
\end{abstract}

(c) 2016 The Research Center for Eco-Environmental Sciences, Chinese Academy of Sciences.

Published by Elsevier B.V.

\section{Introduction}

Eutrophication is especially severe in typical arid rivers of northern China. Reasons for this phenomenon include drought, scarce precipitation, water resource deficiencies, slow flowing rivers caused by dams, and nutrient element ( $\mathrm{N}$ and P) accumulation due to water pollution (Shan et al., 2012; Li et al., 2012; Pernet-Coudrier et al., 2012; Taylor et al., 2015). Eutrophication induces environmental, ecosystem, social and economic problems, such as algal blooms, oxygen depletion, infectious disease, aquatic ecosystem deterioration and freshwater that is unsuitable for human use (Smith and Schindler, 2008; Vörösmarty et al., 2010).

Water resource shortage has been a vital factor affecting the river ecosystems in northern China because of the scarce precipitation and heavy utilization. Most of rivers are dry all the year-round or seasonally. A large amount of untreated wastewater is discharged into the rivers, which has caused many environmental problems, such as eutrophication. As a main tributary of the Hai River system, the Ziya River system

\footnotetext{
* Corresponding author. E-mail: bqshan@rcees.ac.cn (Baoqing Shan).
} 
has also faced the same problems: drought and eutrophication. Agricultural and industrial development in the Ziya River watershed has caused excess exploitation of water resources, so the river is dry year-round or seasonally. This phenomenon is very common and represents a characteristic of arid rivers in northern China (Li et al., 2010a, 2010b). The Fuyang River is an important tributary in the Ziya River system, and flows through large cities such as Handan, Xingtai and Hengshui. There is no rainwater supply, and substantial domestic and industrial wastewater enters the river. The Xingtai segment is seriously polluted in the Fuyang River basin as are the Handan and Hengshui segments, because there are many heavily polluting enterprises along the river, such as leather, paper, chemical and steel industries. The water quality greatly exceeds the criteria of both the USA (US EPA, 1986) and China (National Standard of the People's Republic of China, Environmental Quality Standards for Surface Water, GB3838-2002). This means that the water is unsuitable for any use (Zhao et al., 2014). Point source pollution is serious in heavily populated areas or city areas. Dams and irrigation channels have been constructed along the river, which cause the main channel to flow much more slowly than would otherwise be the case. Dams in river systems produce the characteristic feature of a "reservoir type river". This feature causes nutrient element accumulation and increases the risk of eutrophication (Pernet-Coudrier et al., 2012; Zhang et al., 2014). The eutrophication consumes dissolved oxygen (DO) and affects the metabolism of aquatic organisms, thereby deteriorating the water environment. Thus the study of the Xingtai segment of the Fuyang River has significance for typical arid rivers in northern China.

Temperature and rainfall have clear seasonal variation in northern China. Thus, we hypothesize that the concentrations of nutrient elements and eutrophication vary across the rainy and dry seasons. To describe the spatiotemporal variation of nutrient elements and the influences of and reasons for eutrophication, the Xingtai segment of the Fuyang River basin was chosen as the research object. Twenty-four sample sites were monitored over 2 years. The main objective of this study was to understand the temporal and spatial variations of $\mathrm{N}$ and $\mathrm{P}$, and assess the river eutrophication and environmental factors. Water shortages and eutrophication have been concomitant issues in the rivers in northern China. The main innovation of this study was to reveal the variation trends of nutrient elements and eutrophication and their relationship with environmental factors. This study will furnish some baseline measurements for eutrophication control of arid rivers in northern China or other semi-arid areas that have the same characteristics.

\section{Materials and methods}

\subsection{Study area}

The Xingtai segment is the most polluted part of the Fuyang River basin and is contaminated by various pollutants. This area has extensive plains and substantial agriculture, consisting of wheat, corn and vegetables (Li et al., 2012). The area has a temperate, continental monsoon climate, and most of the rainfall is in summer. In fact, accumulated precipitation in June, July and August accounts for $70 \%$ of annual precipitation (Chun et al., 2009).

The Xingtai segment of the Fuyang River contains the Niuwei, Qili, Xiao, Shunshui, Nanli, Beili, Xiaozhang, Laozhang and Beisha rivers. The river system is very complicated and has many tributaries. The water flow direction is southwest to northeast. The water depth of the research river segment was about 40 and $180 \mathrm{~cm}$ in dry and rainy seasons, respectively. The water flow velocity was about 0.2 and $1 \mathrm{~m}^{3} / \mathrm{sec}$ in dry and rainy seasons, respectively. There are numerous dams and gates, which have caused fragmentation of the river system.

\subsection{Field sampling}

Sampling sites were located along the mainstream and its tributaries as well as drainage rivers in the Xingtai segment. These sites were selected to avoid still water, backwater and discharge outfall areas, and were largely within straight river segments with gentle flow and a wide channel. In total there were 24 sampling sites (sites N1-N5 were in Xingtai City and S1S19 in the suburbs). Detailed locations are shown in Fig. 1. Temperature and precipitation in the study area varies greatly from summer to winter. From January to March, the temperature is low and the rivers freeze up, so it is difficult to collect water samples. From April to June, the floodgates are open, which changes the river flow rate. Thus, sampling was mainly done from July to December. Because of the strong impact of precipitation, sampling frequency was high in the rainy season and low in the dry season. Specifically, samples were taken two or three times monthly from June to September, and once monthly from October to December. There was no obvious rain before sampling. Water samples of $200 \mathrm{~mL}$ were collected by a plexiglass sampler (WB-PM, Beijing Splitter Instrument Co. Ltd.) from mid-river, stored at $4{ }^{\circ} \mathrm{C}$ in a car refrigerator and returned to the lab immediately. The experiments were carried out over 2 days. DO was measured by a YSI portable device (YSI ProPlus, YSI Inc., Yellow Springs, Ohio, USA) at the same location.

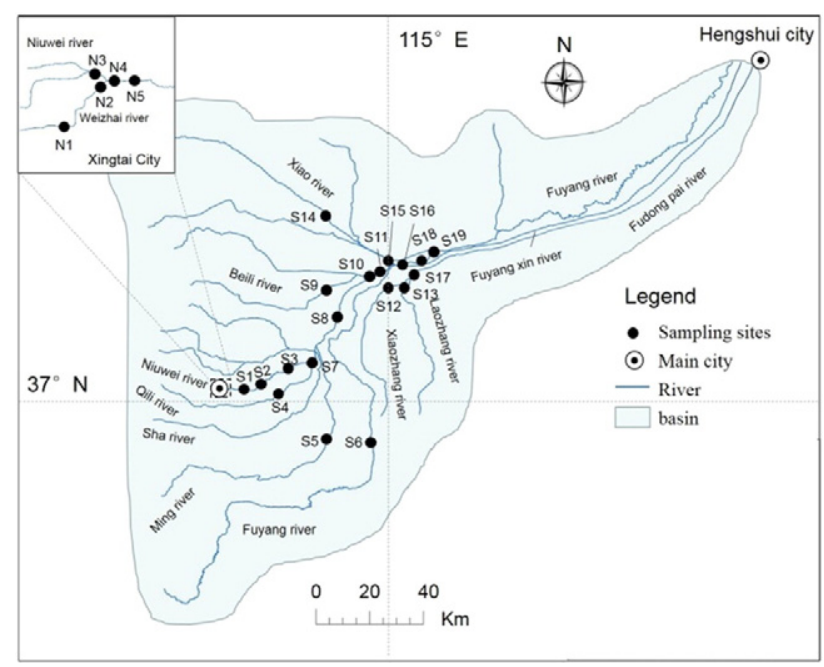

Fig. 1 - Location of sampling sites in Xingtai segment of Fuyang river basin. 


\subsection{Sample analysis}

The index of nutrient elements in water of the Xingtai segment includes the following: total phosphorus (TP), total dissolved phosphorus (TDP), solution reactive phosphorus (SRP), dissolved organic phosphorus (DOP), particulate phosphorus (PP), total nitrogen (TN), total dissolved nitrogen (TDN), ammonia nitrogen $\left(\mathrm{NH}_{3}-\mathrm{N}\right)$, nitrate nitrogen $\left(\mathrm{NO}_{3}-\mathrm{N}\right)$, nitrite nitrogen $\left(\mathrm{NO}_{2}-\mathrm{N}\right)$, particulate nitrogen $(\mathrm{PN})$, and chemical oxygen demand (CODcr). Analysis methods were as follows. TP in water samples was measured using the molybdate colorimetry method after digestion by potassium persulfate $\left(\mathrm{K}_{2} \mathrm{~S}_{2} \mathrm{O}_{8}\right)$. For TDP, samples were filtered using a $0.45-\mu \mathrm{m}$ synthetic fabric filter membrane, and then measured using the same method as for TP. For SRP, filtering was done using that same membrane, and then SRP was measured using the molybdate colorimetry method. DOP was obtained by subtracting TDP and SRP concentrations in the sample (Benitez-Nelson and Buesseler, 1999). PP was obtained by subtraction of TP and TDP. TN in samples was measured using the ultraviolet spectroscopy method after digestion by alkaline potassium persulfate. After sample filtering by a $0.45-\mu \mathrm{m}$ synthetic fabric filter membrane, TDN was measured using the same procedure as for $\mathrm{TN}$. For $\mathrm{NH}_{3}-\mathrm{N}$, the same membrane was used for filtering samples, and then measurement was performed using the indophenol blue spectrophotometric method. For $\mathrm{NO}_{3}^{-} \mathrm{N}$, the same membrane was used for filtering, and measurement was via the ultraviolet spectroscopy method (the chromogenic agent was hydrochloric acid). The membrane was again used for filtering prior to $\mathrm{NO}_{2}^{-} \mathrm{N}$ measurement, which was carried out with the ultraviolet spectroscopy method (the chromogenic agent was sulfanilamide and n-(1-naphthyl)ethylenediamine dihydrochloride); finally, for CODcr, the water sample was measured using the colorimetry method (HACH DR2800) after digestion by a CODcr reagent (HACH DRB200, catalog number 21258-25).

\subsection{Eutrophication index}

Eutrophication assessment was performed according to a universal index equation by a logarithmic power function (eutrophication index: EI), which has been widely used for assessment of lake, reservoir and river water (Li et al., 2010a, 2010b; Shan et al., 2012). The index was assigned five grades: oligotrophic: $\mathrm{EI} \leq 20$; mesotrophic: $20 \leq \mathrm{EI} \leq 39.42$; eutrophic: $39.42 \leq \mathrm{EI} \leq 61.29$; hyper eutrophic: $61.29 \leq \mathrm{EI} \leq 76.28$; and extreme eutrophication: $76.28 \leq \mathrm{EI} \leq 99.77$. The equation is

$\mathrm{EI}=\sum_{j=1}^{n} \mathrm{Wj} \times \mathrm{EI}_{j}=10.77 \times \sum_{j=1}^{n} \mathrm{Wj} \times\left(\operatorname{In} X_{j}\right)^{1.1826}$

where, $W_{j}$ is a normalized weighted value of index $j$. Weights of various indexes in this study were equal. $\mathrm{EI}_{\mathrm{j}}$ is the eutrophication evaluation universal index of index $j . X_{j}$ is the code value of that index.

\section{Results and discussion}

\subsection{Physicochemical characteristics of river water}

Physicochemical characteristics of river water are shown in Fig. 2. Concentrations of CODcr ranged from 10 to $388 \mathrm{mg} / \mathrm{L}$. The average concentration of CODcr in the river water was $53.0 \mathrm{mg} / \mathrm{L}$, higher than water quality criteria (criterion $\mathrm{V}$, $40 \mathrm{mg} / \mathrm{L}$ ) (National Standard of the People's Republic of China, Environmental Quality Standards for Surface Water, GB3838-2002). CODcr concentrations $>40 \mathrm{mg} / \mathrm{L}$ were found at $52.0 \%$ of sample sites. There are many reasons for such high CODcr concentrations in the Xingtai segment, such as industrial and agricultural discharges and domestic sewage and rubbish. The concentration of DO ranged from 0.1 to $3.9 \mathrm{mg} / \mathrm{L}$. The average
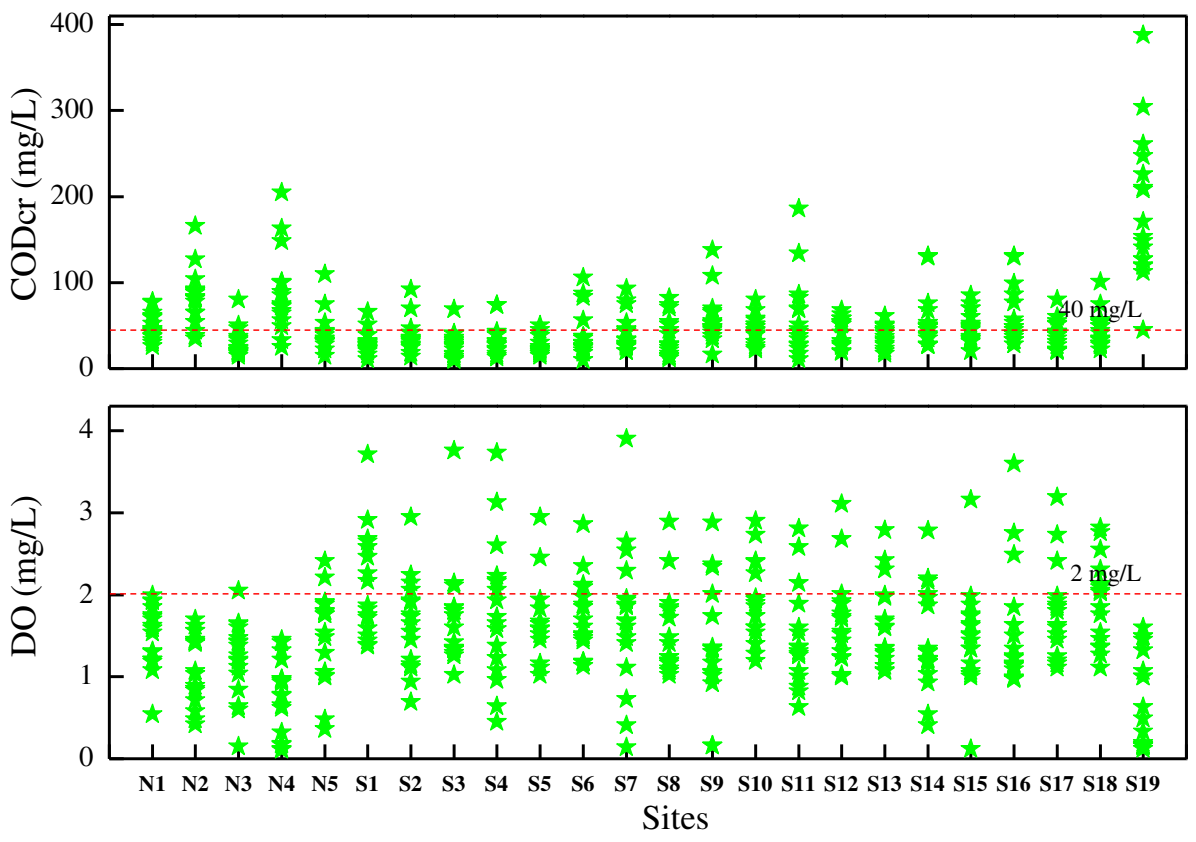

Fig. 2 - Spatial variation of CODcr and DO in the water of Xingtai segment of Fuyang river basin. 
concentration of DO was $1.6 \mathrm{mg} / \mathrm{L}$, lower than water quality criteria (criterion V, $2 \mathrm{mg} / \mathrm{L}$ ) (GB3838-2002). DO concentrations $<2 \mathrm{mg} / \mathrm{L}$ were found at $79.6 \%$ of all sample sites. This means that the quality was unfit for aquatic organism metabolism. The reason for this was oxygen-demanding waste, such as CODcr and $\mathrm{NH}_{3}-\mathrm{N}$ (Li et al., 2012).

CODcr and DO were markedly increased and decreased at site 19 (which is located in Aixinzhuang Dam) respectively. These changes in the front of the dam are attributable to the slow flowing water. This caused pollution accumulation, which is especially serious for arid rivers, and then degraded water quality (Zhang et al., 2016). This is a universal phenomenon in typical arid rivers of northern China (Pernet-Coudrier et al., 2012). CODcr and DO showed negative correlation, which meant that the CODcr and DO had opposite variation trends. For sites having high CODcr concentration, the DO concentration was low. On the spatial scale, the contents of DO and CODcr were lower and higher respectively in the city segment than in the suburban segment, which indicated that human activities were the most significant factors affecting river ecosystem health.

\subsection{Temporal and spatial variation of nitrogen and phosphorus}

Temporal variation of $\mathrm{TN}, \mathrm{NH}_{3}-\mathrm{N}, \mathrm{NO}_{3}-\mathrm{N}, \mathrm{NO}_{2}-\mathrm{N}, \mathrm{PN}, \mathrm{DOP}, \mathrm{SRP}$ and $\mathrm{PP}$ in water of the Xingtai segment is shown in Fig. 3. The
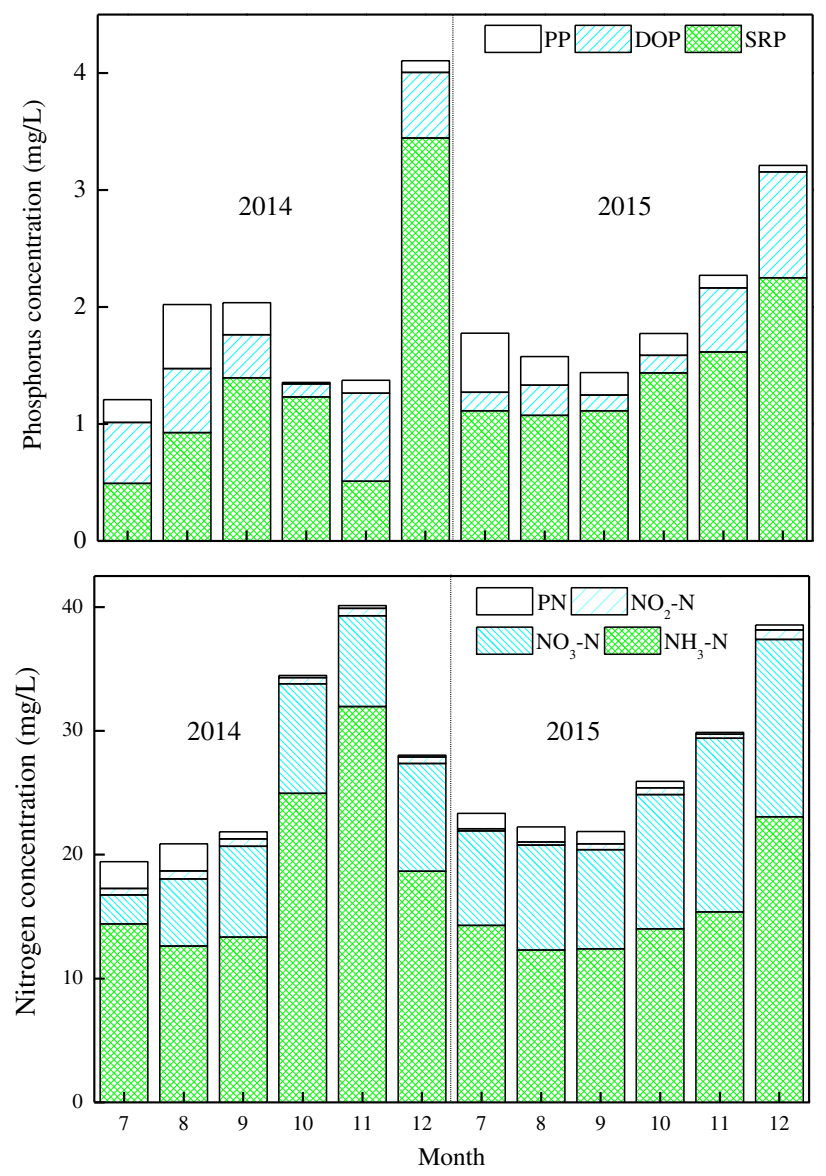

Fig. 3 - Temporal variation of different component of $P$ and $N$ in the water of Xingtai segment of Fuyang river basin. main components of $\mathrm{N}$ were $\mathrm{NH}_{3}-\mathrm{N}$ and $\mathrm{NO}_{3}-\mathrm{N}$, accounting for $63.5 \%$ and $31.6 \%$ of TN. SRP and DOP were the main constituents of $\mathrm{P}$, representing $68.8 \%$ and $20.7 \%$ of TP. This indicated that most nutrient elements were available for aquatic organisms, which was different from other large rivers, such as the Yellow River (Jarvie et al., 2012; Pan et al., 2013; Zhang et al., 2016). A large amount of solution $\mathrm{N}$ and $\mathrm{P}$ can support the metabolism of an abundance of aquatic organisms, such as algae.

The study region has a temperate continental monsoon climate. Although pollution accompanies rainfall, heavy rain dilutes it (Dhia et al., 2008), and a large number of aquatic plants absorb nutrient elements. These combined actions lead to lower concentrations of $\mathrm{N}$ and $\mathrm{P}$ in the rainy season (Haggard et al., 1999). Conversely, near-complete drying of the flow during the dry season concentrates nutrients, and aquatic plant residue decomposes and releases nutrients into surface water (Correll, 1998). Therefore, N and P concentrations are higher in the dry season than in the rainy season in arid rivers of northern China.

The spatial variation of various $\mathrm{N}$ and $\mathrm{P}$ components in the water of the Xingtai segment was also studied (Fig. 4). Sample sites were in urban (N1 to N5) and suburban (S1 to S19) areas. The main components, $\mathrm{SRP}, \mathrm{NH}_{3}-\mathrm{N}$ and $\mathrm{NO}_{3}-\mathrm{N}$, had higher concentrations in urban areas than suburban ones. Xingtai City has many heavily polluting enterprises, such as those in the paper and steel industries. Part of the untreated wastewater and domestic sewage from these sources flows into the river, and an artificial river bank reduces the self-purification capability in the city segment, both of which cause accumulation of $\mathrm{N}$ and $\mathrm{P}$ in river water (Li et al., 2012). Although some agricultural wastewater enters the river, a more integrated littoral zone ensures that river water has vigorous self-purification (Zhang et al., 2014). Therefore, the nutrient elements had higher concentrations in urban areas than in suburban ones.

$\mathrm{N}$ and $\mathrm{P}$ concentrations were 13 and 5 times higher than the surface water quality standards, respectively (GB3838-2002). Most $\mathrm{N}$ and $\mathrm{P}$ were bioavailable, and the ratios of SRP to TP and $\mathrm{NH}_{3}-\mathrm{N}$ to $\mathrm{TN}$ were $68.75 \%$ and $63.51 \%$, respectively. The relative abundance of $\mathrm{N}$ and $\mathrm{P}$ represent the relationship of $\mathrm{N}$ and $\mathrm{P}$ input loads, as well as the effect of nutrient input on the water nutrient structure (Hans, 2006). Plant metabolism requirements vary with nutrient element ratio. Therefore, the seasonal variation of $\mathrm{N}$ and $\mathrm{P}$ change the characteristics of nutrient restriction, which is the key factor regulating the alternation of aquatic organism growth (Smith, 1983). According to nutrient restriction classification standards, TN/TP $\geq 22.6$ indicates a $\mathrm{P}$ deficiency and TN/TP $\leq 9.0$ a N deficiency (Guildford and Hecky, 2000). TN/TP ranged from 6.8 to 29.2 , and was $\geq 22.6$ and $\leq 9.0$ in November and December, respectively, revealing $\mathrm{P}$ and $\mathrm{N}$ deficiencies. A possible reason for this is phytoplankton decomposition and microbial metabolism (Hans, 2006).

On the time scale, the $\mathrm{N}$ and $\mathrm{P}$ contents were higher in the dry season than in the rainy season. On the spatial scale, the city segment had higher $\mathrm{N}$ and $\mathrm{P}$ concentrations than the suburban segment. Also, bioavailable $\mathrm{N}$ and $\mathrm{P}$ were the main components in the rivers. The three factors' synergistic effect induce the city segment to have a higher risk of algae bloom in the dry season. Thus we should pay more attention to the river ecological restoration and pollution control in the city segment to increase the health of the river ecosystem. 

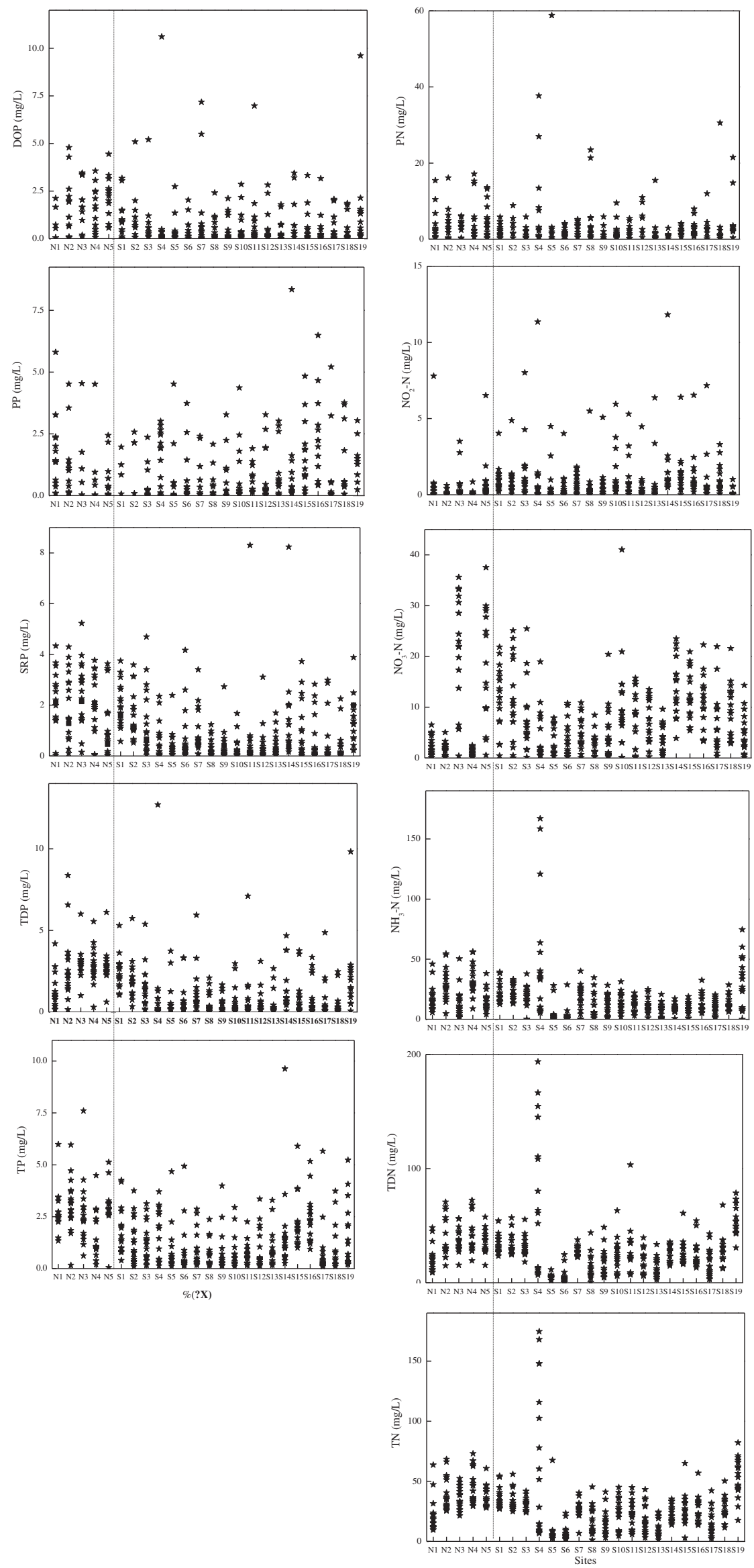

Fig. 4 - Spatial variation of different component of $\mathrm{P}$ and $\mathrm{N}$ in the water of Xingtai segment of Fuyang river basin. 


\subsection{Eutrophication index in typical arid rivers of northern China}

The EI is shown in Fig. 5. Water quality was in a state of extreme eutrophication year-round ( $E I \geq 76.3)$. The smallest and largest EI occurred in July (93.7) and December (101.6) of 2014 , respectively. The average EI was 97.5 over 2 years. The EI was larger in the dry season than in the rainy season. Changes in the index matched those of $\mathrm{N}$ and $\mathrm{P}$. The EI progressively increased from July through December in the study period. Spatial variation of EI in the water of the Xingtai segment was also examined (Fig. 5). The average EI at urban sample sites $\left(\mathrm{EI}_{\mathrm{ave}}=98.8\right)$ was larger than at suburban sites $\left(\mathrm{EI}_{\mathrm{ave}}=93.4\right)$.

$\mathrm{N}$ and $\mathrm{P}$ exceeded water quality standards and produced eutrophication in the watershed. Water eutrophication in the Xingtai segment was assessed by the EI. The surface water was in an extreme eutrophication state. Substantial rainfall and dam opening in the rainy season diluted $\mathrm{N}$ and $\mathrm{P}$, leading to a smaller EI. The lower precipitation in the dry season reduces vital water recharge. Dam closure to preserve water in the dry season retards water flow. Another factor is strong evaporation during that season in northern China. The above factors produce larger EI during the dry season in typical arid rivers of northern China. Spatially, EI was higher in urban areas, because of pollution accumulation and loss of river habitat (Anderson et al., 2002; Lei et al., 2012). Eutrophication produces algae blooms and environmental, ecosystem, social and economic problems, such as oxygen depletion, infectious disease, aquatic ecosystem deterioration, and freshwater that is unsuitable for human use (Xia et al., 2006; Smith and Schindler, 2008; Vörösmarty et al., 2010). This phenomenon restricts economic and social development.

\subsection{Relationships between EI and the nutrition element}

Relationships between the EI and $\mathrm{N}$ and $\mathrm{P}$ concentrations are shown in Table 1. $\mathrm{NH}_{3}-\mathrm{N}$ and SRP were found to be positively correlated with TN and TP, respectively $\left(R^{2}=0.917\right.$ and 0.946 , $p<0.01$ ), which demonstrated that the bioavailable $\mathrm{N}$ and $\mathrm{P}$ were the dominant components in the arid rivers of northern

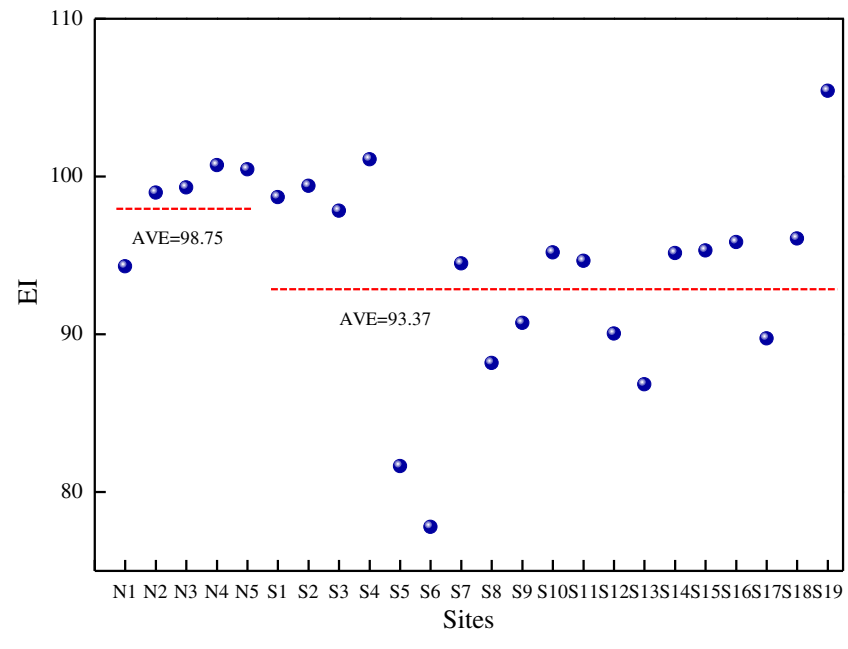

China because of the pollution input accompanying the social and economic development (Pernet-Coudrier et al., 2012). This study indicated that reactive $\mathrm{N}$ and $\mathrm{P}$ were the most significant factors for EI because of the positive correlation between $\mathrm{NH}_{3}-\mathrm{N}$, SRP and EI $\left(R^{2}=0.662\right.$ and $\left.0.609, p<0.05\right)$. As an important phosphorus source, the DOP can support aquatic organism metabolism (Benitez-Nelson and Buesseler, 1999; Dyhrman et al., 2005). But no relationship was found between the DOP and other environmental factors, especially EI, which indicated that DOP might be just a standby phosphorus source in freshwater ecosystem. The small amounts of $\mathrm{N}, \mathrm{NO}_{3}-\mathrm{N}$ and $\mathrm{NO}_{2}-\mathrm{N}$ had no relationship with the EI, which indicated that they made little or no contribution to river eutrophication. Positive correlations between PP and PN $\left(R^{2}=0.708, p<0.01\right)$ showed that they have the same origins, non-point source pollution from storm runoff and untreated wastewater from livestock breeding and domestication (Laing et al., 2005; Xiong and Wan, 2008; Peng et al., 2012; Duan et al., 2015). The negative relationship between PP, PN and EI also indicated that the particulate $\mathrm{N}$ and $\mathrm{P}$ does not augment the risk of eutrophication in arid rivers of northern China (Huang et al., 2002; Kuang et al., 2015). This hypothesis was confirmed for these arid rivers through this systematic study. The study not only verified that the concentrations of nutrient elements and eutrophication varied across the rainy and dry seasons, but also found that the nutrient element contents varied on the district scale. This study indicates that the management of bioavailable and particulate $\mathrm{N}$ and $\mathrm{P}$ are vital for eutrophication control in arid rivers in northern China.

\section{Conclusions}

(1) $\mathrm{N}$ and $\mathrm{P}$ were higher in the rainy season than in the dry season. SRP, $\mathrm{NH}_{3}-\mathrm{N}$ and $\mathrm{NO}_{3}-\mathrm{N}$, had higher concentrations in urban areas than in suburban areas.

(2) Water quality was in a state of extreme eutrophication year-round ( $\mathrm{EI} \geq 76.28$ ). The smallest and largest EI occurred in July (93.7) and December (101.6) of 2014, respectively. The average EI over the studied 2 years was 97.5.

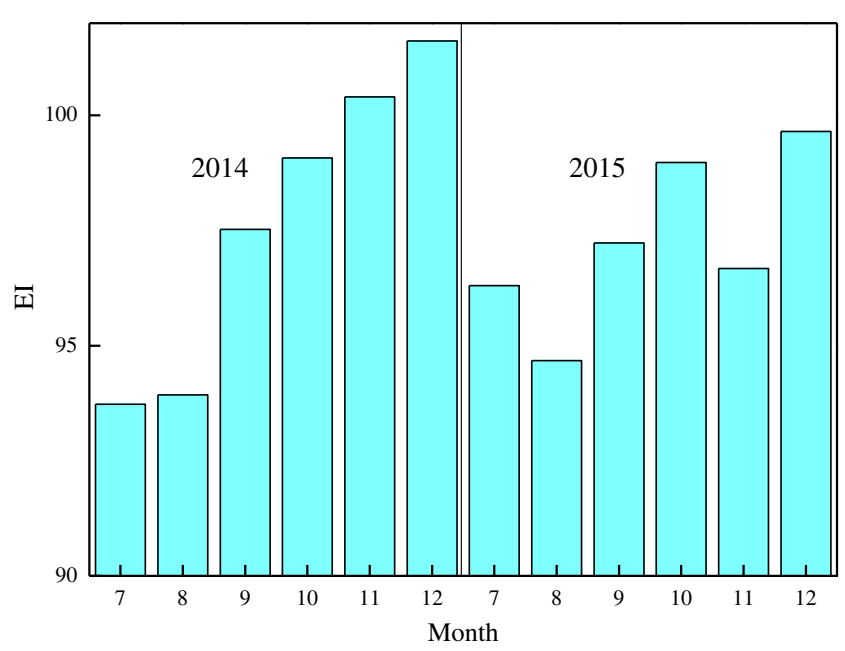

Fig. 5 - Eutrophication index (EI)values of the water in Xingtai segment of Fuyang river basin. 
Table 1 - Pearson correlation coefficients for physicochemical characteristics in the Niuwei River

\begin{tabular}{|c|c|c|c|c|c|c|c|c|c|c|c|c|}
\hline & $\mathrm{NH}_{3}-\mathrm{N}$ & $\mathrm{NO}_{3}-\mathrm{N}$ & $\mathrm{NO}_{2}-\mathrm{N}$ & PN & DTN & $\mathrm{TN}$ & SRP & DOP & PP & DTP & $\mathrm{TP}$ & EI \\
\hline $\mathrm{NH}_{3}-\mathrm{N}$ & 1 & 0.190 & 0.364 & -0.557 & $0.905^{* *}$ & $0.917^{* *}$ & 0.028 & 0.472 & -0.573 & 0.163 & 0.060 & $0.662^{*}$ \\
\hline $\mathrm{NO}_{3}-\mathrm{N}$ & & 1 & -0.002 & $-0.705^{*}$ & $0.589^{*}$ & 0.561 & 0.515 & 0.193 & -0.454 & 0.516 & 0.456 & 0.482 \\
\hline $\mathrm{NO}_{2}-\mathrm{N}$ & & & 1 & -0.061 & 0.318 & 0.336 & 0.153 & 0.566 & -0.255 & 0.302 & 0.269 & 0.339 \\
\hline PN & & & & 1 & $-0.761^{* *}$ & $-0.716^{* *}$ & -0.520 & -0.097 & $0.708^{* *}$ & -0.492 & -0.381 & $-0.864^{* *}$ \\
\hline DTN & & & & & 1 & $0.998^{* *}$ & 0.250 & 0.481 & $-0.669^{*}$ & 0.363 & 0.253 & $0.756^{* *}$ \\
\hline $\mathrm{TN}$ & & & & & & 1 & 0.215 & 0.508 & $-0.647^{*}$ & 0.340 & 0.233 & $0.724^{* *}$ \\
\hline SRP & & & & & & & 1 & 0.227 & -0.336 & $0.959^{* *}$ & $0.946^{* *}$ & $0.609^{*}$ \\
\hline DOP & & & & & & & & 1 & -0.230 & 0.494 & 0.476 & 0.217 \\
\hline PP & & & & & & & & & 1 & -0.367 & -0.192 & $-0.627^{*}$ \\
\hline DTP & & & & & & & & & & 1 & $0.983^{* *}$ & $0.607^{*}$ \\
\hline $\mathrm{TP}$ & & & & & & & & & & & 1 & 0.518 \\
\hline EI & & & & & & & & & & & & 1 \\
\hline
\end{tabular}

PN: particulate nitrogen; TN: total nitrogen; SRP: solution reactive phosphorus; DOP: dissolved organic phosphorus; PP: particulate phosphorus; TP: total phosphorus; EI: eutrophication index; DTN: dissolved total nitrogen; DTP: dissolved total phosphorus.

${ }^{*}$ Correlation is significant at the 0.05 level (2-tailed).

** Correlation is significant at the 0.01 level (2-tailed).

(3) The EI was larger in the dry season than in the rainy season, which showed the same trend as $\mathrm{N}$ and $\mathrm{P}$. The EI progressively increased from July to December during the study period. The average EI of urban sample sites $\left(E I_{\text {ave }}=98.8\right)$ was larger than that of suburban district sites $\left(\mathrm{EI}_{\mathrm{ave}}=93.4\right)$.

\section{Acknowledgments}

This work was supported by the National Natural Science Foundation of China (No. 21507146) and the National Water Pollution Control and Management Technology Major Projects of China (Nos. 2012ZX07203-006 and 2012ZX07203-003).

\section{R E F E R E N C E S}

Anderson, D.M., Glibert, P.M., Burkholder, J.M., 2002. Harmful algal blooms and eutrophication: nutrient sources, composition and consequence. Estuar. Coasts 25, 704-726.

Benitez-Nelson, C.R., Buesseler, K.O., 1999. Variability of inorganic and organic phosphorus turnover rates in the coastal ocean. Nature 398, 502-505.

Chun, J.T., Xia, J., Xu, C.Y., Li, L., Wang, Z.G., 2009. Comparison and spatial-temporal variability of daily precipitation data of weather station and rain gauges in Haihe river basin. J. Geogr. Sci. 4, 1083-1092.

Correll, D.L., 1998. The role of phosphorus in the eutrophication receiving waters: a review. J. Environ. Qual. 27, 261-266.

Dhia, A.B., Rhaman, S., Bowling, L., 2008. Bowling, sources and management of urban stormwater pollution in rural catchments, Australia. J. Hydrol. 356, 299-311.

Duan, S.H., Zhao, Y., Shan, B.Q., Tang, W.Z., Zhang, W.Q., Zhang, S.Z., et al., 2015. Research of the stormwater runoff and pollution characteristics in rural area of Yuhang District,Hangzhou. Environ. Sci. 36, 3697-3705.

Dyhrman, S.T., Chappell, P.D., Haley, S.T., Moffett, J.W., Orchard, E.D., Waterbury, J.B., Webb, E.A., 2005. Phosphonate utilization by the globally important marine diazotroph Trichodesmium. Nature 439, 68-71.

Guildford, S.J., Hecky, R.E., 2000. Total nitrogen, total phosphorus and nutrient limitation in lakes and oceans: is there a common relationship? Limnol. Oceanogr. 45, 1213-1223.
Haggard, B.E., Stanley, E.H., Hyler, R., 1999. Sediment-phosphorus relationships in three northcentral Oklahoma streams. Trans. ASABE 42, 1709-1714.

Hans, W.P., 2006. Assessing and managing nutrient-enhanced eutrophication in estuarine and coastal waters: interactive effects of human and climatic perturbations. Ecol. Eng. 26, 40-54.

Huang, M.X., Zhou, C.H., Zhang, S., Wang, Q.F., 2002. Sediment transport and enrichment mechanisms of nitrogen and phosphorus under simulated rainfall condition. J. Soil Water Conserv. 16 (13-16), 33.

Jarvie, H.P., Sharpley, A.N., Scott, J.T., Haggard, B.E., Bowes, M.J., Massey, L.B., 2012. Within-river phosphorus retention: accounting for a missing piece in the watershed phosphorus puzzle. Environ. Sci. Technol. 46, 13284-13292.

Kuang, W., Rui, M., Zhang, Y.H., Yan, Y.Z., Wu, T.T., 2015. Effect of nitrogen and phosphorus on rainstorm runoff reduction cut from ecological restoration engineering of Chaohu lakeside zone. Resour. Environ. Yangtze Basin 24, 1906-1912.

Laing, T., Wang, H.P., Zhang, X.M., Yuan, J.W., Zhang, S., 2005. Simulation study of non-point source pollution under different landuse in Guanting reservoir watershed. Acta Sci. Circumst. $25,483-490$.

Lei, P., Zhang, H., Shan, B.Q., 2012. Dynamic characteristics of nitrogen and phosphorus in the representative input tributaries of Danjiangkou reservoir. Environ. Sci. 33, 3038-3045.

Li, S.Z., Han, N., Xia, J.X., 2010a. Flood control planning of the Ziya river basin. J. Cent. National. Univ. 19, 13-22.

Li, W.Z., Li, X.Y., Wang, H.L., Su, J.J., 2012. Spatial distribution of the main contamination in aquatic environment in Fuyang river. J. Environ. Sci. 2, 2814-2819.

Li, Z.Y., Wang, J.Y., Guo, C., 2010b. A universal index formula for eutrophic evaluation using a logarithmic power function. J. Environ. Sci. 30, 664-672.

National Standard of the People's Republic of China, Environmental Quality Standards for Surface Water, GB3838-2002.

Pan, G., Krom, M.D., Zhang, M.Y., Zhang, X.W., Wang, L.J., Dai, L.C., Sheng, Y.Q., 2013. Impact of suspended inorganic particles on phosphorus cycling in the Yellow River (China). Environ. Sci. Technol. 47, 9685-9692.

Peng, L., Wang, L.W., Yang, Z.M., Chen, Y.C., Qiao, J.J., Zhao, Z.J., 2012. Effects of rainfall on nitrogen and phosphorus loss from courtyard compost and its risk of nonpoint source pollution. Environ. Sci. 33, 407-411.

Pernet-Coudrier, B., Qi, W.X., Liu, H.J., Müller, B., Michael, B., 2012. Sources and pathways of nutrients in the semi-arid region of Beijing-Tianjin, China. Environ. Sci Technol 46, 294-5301. 
Shan, B.Q., Jian, Y.X., Tang, W.Z., Zhang, H., 2012. Temporal and spatial variation of nitrogen and phosphorus and eutrophication assessment in downstream river network area of north canal river watershed. Environ. Sci. 3, 352-358.

Smith, V.H., 1983. Low nitrogen to phosphorus rations favor dominance by blue-green algae in lake phytoplankton. Science 221, 669-671.

Smith, V.H., Schindler, D.W., 2008. Eutrophication science: where do we go from here? Trends Ecol. Evol. 24, 201-207.

Taylor, M., Christopher, T.P., Christine, R., Severin, S., Hans, H.D., Helen, R.P., et al., 2015. Global phosphorus retention by river damming. Proc. Natl. Acad. Sci. U. S. A. 112, 15603-15608.

US EPA, 1986. Quality Criteria For Water - 1986 (EPA 440/5-86-001).

Vörösmarty, C.J., Mclntyre, P.B., Gessner, M.O., Dudgeon, D., Prusevich, A., Green, P., et al., 2010. Global threats to human water security and river biodiversity. Nature 467, 555-561.
Xia, B., Zhang, L.J., Gui, Z.S., Jiang, C.B., 2006. The eutrophication condition and the pollutant fluxes entering the sea via the rivers in the Haihe river basin. J. Ocean Univ. China 12, 33-38.

Xiong, H.F., Wan, X.H., 2008. Investigation of nitrogen and phosphorus loadings on Liangzi lake from agricultural non-point source. Environ. Sci. Technol. 31, 25-27.

Zhang, Q., Hirsch, R.M., Ball, W.P., 2016. Long-term changes in sediment and nutrient delivery from Conowingo dam to Chesapeake Bay: effects of reservoir sedimentation. Environ. Sci. Technol. 50, 1877-1886.

Zhang, W.Q., Shan, B.Q., Zhang, H., Tang, W.Z., 2014. Phosphorus-31 nuclear magnetic resonance assignments of biogenic phosphorus compounds in sediment of an artificial Fuyangxin river, China. Environ. Sci. Pollut. Res. 21, 3803-3812.

Zhao, Y., Shan, B.Q., Zhang, W.Q., Wang, C., 2014. Forms and spatial distribution characteristics of nitrogen in Ziya river basin. Environ. Sci. 35, 144-149. 